51; Edinburgh and London: H.M. Stationery Office, $1950 ; 18$.$) , gives a detailed account of the$ biology and control of this insect. The authors attach more importance to poison baits than to contact insecticides as a means of control. Pieces of liver are smeared at suitable points, with the object of locating the nests and establishing regular trails. This is termed 'pre-baiting'. The poison bait, consisting of thallium sulphate and sodium fluoride mixed with syrup and liver or minced meat, or of sodium silico-fluoride and dried liver, is securely enclosed in tins suitably perforated to allow access by the ants and placed in the line of the established trails. The poison bait must be renewed once a week, and it is usuelly necessary to continue the process for six months or more before the entire brood in the nests has been effectively poisoned. Needless to say, these measures will be successful only if they are combined with a campaign for general hygiene and cleanliness.

\section{Anniversary of Elliott Brothers, Instrument Makers}

As a part of the celebrations this year of its 150th anniversary, the firm of Elliott Brothers (London), Ltd., is compiling a record of its activities and would like to hear of the whereabouts of Elliott instru. ments made during the nineteenth century. The firm originally made drawing and surveying instruments and acquired the business of Watkins and Hill about the middle of the past century. The available catalogues show that the products included many types of optical apparatus, as well as electrical apparatus which was supplied to the early experimenters. The company developed a calculating machine known as the arithmometer and, towards the end of the century, supplied a wide range of electrical indicating and recording instruments and telegraphic apparatus. Unfortunately, many specimens of this old apparatus and interesting photographs were destroyed during the Second World War, and the company would welcome any information about their early products. Correspondence should be addressed to Mr. A. H. Attwood, Elliott Brothers (London), Ltd., Century Works, Lewisham, S.E.13.

\section{University of Glasgow}

For the new session this year 250 new admissions have been made to the Science Faculty of the University of Glasgow. Altogether the University now has 6,645 matriculated students $\langle 5,298$ men, 1,347 womgn), which is about 350 fewer than a year ago. In the Department of Chemistry, N. Grassie and $V$. Vand have been appointed Imperial Chemical Industries, Ltd., fellows. Dr. Grassie, a graduate of Aberdeen, will continue his study of the kinetics of high-polymer reactions which he started at the University of Birmingham. Dr. Vand graduated in physics and mathematics at the Charles University, Prague, and goes to Glasgow from Lever Brothers and Unilever, Ltd. ; his work is in the field of X-ray crystal analysis and has special reference to mech. anical methods of computation. Dr. R. P. Korf, a mycologist from the Department of Plant Pathology, Cornell University, with a particular interest in the taxonomy of the Discomycetes, is at the Botany Department of the University for a year on an exchange with Dr. S. A. Hutchinson. The librarian and keeper of the Hunterian Books and MSS., Dr. W. R. Cunningham, has resigned as from March 31, 1951.

\section{Institution of Civil Engineers : Awards}

THE Institution of Civil Engineers has announced the following awards for papers reid at meetings or published in the Journal during the session 1949-50. Telford Premiums: R. G. Braithwaite and D. J. Davies, jointly, for their paper on "Welded Highway Bridges"; and G. M. Binnie for his paper on "Some Notes on the Karun River and the Shatt-el-Arab". Telford Premiums for papers read at meetings of the following Engineering Divisions: Railway Engineer ing Division, A. H. Toms and W. F. Beatty; Structural and Building Engineering Division, W. S. A. Atkins; Works Construction Division, D. Lumbard and A. A. Wright; Maritime and Waterways Engineering Division, R. A. Stephenson; Airport Engineering Division, F. S. Snow. Coopers Hill War Memorial Prize to Dr. A. S. Thom for his paper on "Investigation of Tidal Phenomena in the Clyde Estuary, using a Scale Model". Indian Premium to Rai Bahadur B. B. Gupta for his paper on "Some Causeways on Sand Foundations across Rivers in India and their Development to Submersible Bridges". Miller Prizes for papers by students of the Institution to: A. Moores, P. Heatly, C. B. Wilby, J. A. G. Clarke, J. R. Willetts, R. J. Anderson, D. J, D. Wood, D. J. Skinner and H. E. Elliott. Institution Medal and Premium for a paper by an undergraduate of the University of London to $\mathbf{J}$. R. Taylor.

\section{Institute of Navigation}

The following have been appointed officers for 1950-51 of the Institute of Navigation : President, Sir Robert Watson.Watt; Vice-Presidents, AirCommodore C. E. Chilton and Captain G. C. Saul ; Honorary Treasurer, F. G. G. Carr ; Chairman of the Technical Committee, R. F. Hansford; Chairman of the Executive Committee, L. P. Kirwan; Other Members of the Council, Dr. E. Adams, E. L. T. Barton, Air Chief Marshal Sir Frederick Bowhill, Francis Chichester, Commander C. E. N. Frankcom, A. H. Jessell, Commander W. E. May, D. H. Sadler, Sir Harold Spencer Jones, Captain G. W. Wakeford and Captain F. J. Wylie.

Rear-Admiral Gordon MeLintock, U.S.M.S., and Admiral of the Fleet Sir Henry Oliver have been made honorary fellows of the Institute.

\section{International Congresses during 1951}

IN 1951 the following meetings associated with international scientific unions which are members of the International Council of Scientific Unions will take place. Astronomy : The Eighth General Assembly of the International Astronomical Union will be held in Leningrad and Pulkovo during August 1-8. Chemistry: The Sixteenth Conference of the International Union of Pure and Applied Chemistry com. mences in New York during September 8-9 after the meetings of the American Chemical Society (Septem. ber 3-7), and will be concluded in Washington, D.C., during September 14-15, on which dates the National Bureau of Standards in Washington will be celebrating its fiftieth anniversary. The Twelfth International Congress of Pure and Applied Chemistry will be held in New York during September 10-13. Crystallography: The Second General Assembly and Congress of the International Union of Crystallography will be held in Stockholm during June 27-July 3. Following this there will be two symposia, on advanced techniques in structure determination and on olectron 